\title{
Analysis of the Factors Influencing the Growth of Small and Medium-Sized Enterprises in Colombia
}

\author{
Ignacio Barrios Parejo* , Hugo Hernández Palma, Leonardo Niebles Núñez, \\ Danilo Hernández Rodríguez, Wiliam Niebles Núñez \\ 1-4Universidad del Atlántico, ${ }^{5}$ Universidad de Sucre \\ ignaciobarrios@mail.uniatlantico.edu.co,hugohernandezp@mail.uniatlantico.edu.co, leonardodnn@yahoo.es, \\ danilohernandez@mail.uniatlantico.edu.co,williamniebles@yahoo.com.mx
}

\begin{abstract}
Objective: This article analyses the factors that influence the growth of small and medium-sized enterprises in Colombia, taking as a reference the last major survey carried out on this type of enterprise in the first quarter of the current year. Methodology: A descriptive/quantitative research is proposed for the study, based on the figures provided by the National Association of Financial Institutions, which in partnership with organizations such as Bancoldex, Confederation of Chamber of Commerce, Bank of the Republic and National Guarantee Fund, interviewed 1454 micro entrepreneurs between January and March 2018. Recommendations: The information presented here allows us to project a scenario that is conducive to strengthening the business sector and suggests in particular that we continue to encourage formalization channels. Conclusion: SMEs continue to be a very significant component of the country's economy, and initiatives to strengthen and sustainably promote them must continue to be promoted in the city.
\end{abstract}

Keywords: Small and Medium Enterprises (SMEs), Economic Development, Competitiveness, entrepreneurship.

\section{Introduction}

In Colombia, small and medium-sized enterprises (SMEs) are considered an important source of labor generation with ample flexibility in their operations $s^{-1}$ and they contribute to the Gross Domestic Product (GDP), to productivity growth, as well as to the growth of international trade. In general, low levels of capital requirements, high birth and death rates, active participation of family members as owners or partners, centralized power, hiring of diverse hands, limited resources for innovation, etc.2, characterize SMEs in Latin America.

These organizations are confronted with many factors that contribute to their growth, but at the same time they face many barriers, which can be of two types, institutional and financial; the first is associated with the interaction that the company manages with government entities in relation to legalization procedures, taxes and government support; the second has to do with the lack of financial resources 2 . In addition to the above factors, researchers have determined that SMEs also face internal barriers along with social barriers, which affect aspects such as their position in the market, access to suitable human resources and the technological network. In the same way, it is considered that small companies are dependent on the vision of the owner, management skills, training, education and background of the company's leader ${ }^{3}$.

In general, the factors influencing SMEs can be divided into internal and external ${ }^{1}$ :

- External factors: are those that are beyond the control of the company, which include economic, socio-cultural, regulatory and legal, political, financial, commercial, technological, demographic, geophysical, etc.; are those that provide opportunities or threats from the environment. The demographic environment includes factors such as size, growth rate, population composition by age or gender; the analysis of these factors

*Author for correspondence 
is important, as the heterogeneity of demographics marked by the diversity of tastes, preferences, beliefs, or temperaments, affects market demand, from which companies establish their strategies ${ }^{4}$.

- Internal factors: are those that are controllable, such as personnel, strategy, operation, marketing, and finance and technical skills. It comprises resources, synergy and distinctive competencies of a company, which determine the internal aspects of the organization as well as its internal strengths and weaknesses ${ }^{5}$.

- Once the organizational and environmental factors have been evaluated, the organization is able to map out its strategies to carry out the planned objectives. A flexible organizational structure allows the organization to respond quickly and effectively to changes in the market, making the capacity of staff one of the most important factors influencing the business environment related to the existence and use of human resources.

The development of a successful management depends in great percentage on the people who participate in it; the competitive environment in which companies operate, require new forms of commitment to be aware of the facts, decide, direct, think and feel, including the administration of human relations for more effective communication ${ }^{6}$. Strategic human resources management has emerged as a dominant approach in human resources management policy over the past 30 years $^{7}$, whereby the formulation and promulgation of a human resources strategy must be designed in alignment with strategic objectives ${ }^{-}$. Over the course of this time, the human resources function has undergone major changes, where professionals have become business partners, which is why strategies must be oriented both to seek success and to achieve sustainability ${ }^{8-9}$.

Human resource management requires that business leaders evaluate their talent pool on an ongoing basis to determine whether the experience needed to achieve the strategies is available within the organization ${ }^{10-11}$, as well as to identify the skills that can be developed in employees to achieve the level needed in the organization to be competitive ${ }^{7}$. The relationship between the strategy proposed towards the development of innovation and human resources policy has a positive impact on the achievement of an innovative culture ${ }^{12}$. The intangible resources are those based on knowledge, which make up the aspects of business competitiveness, mostly used by organizations, becoming the intellectual capital $\frac{13}{}$.

\section{Methodology}

A descriptive/quantitative research is proposed for the study, based on the figures provided by the National Association of Financial Institutions, which in partnership with organizations such as Bancoldex, Confederation of Chamber of Commerce, Bank of the Republic and National Guarantee Fund, interviewed 1454 micro entrepreneurs between January and March 2018. The analyses to be carried out will be of a differentiating nature and will focus on characterising the relevant aspects that allow for reflection on the factors that have the greatest influence on the life of SMEs in the city.

\section{Results}

According to the data published by the National Association of Financial Institutions (ANIF), for the Large Survey of Microenterprises (GEM), 1454 SMEs were surveyed nationwide; they are distributed in three main economic lines, which are shown in Figure 1.

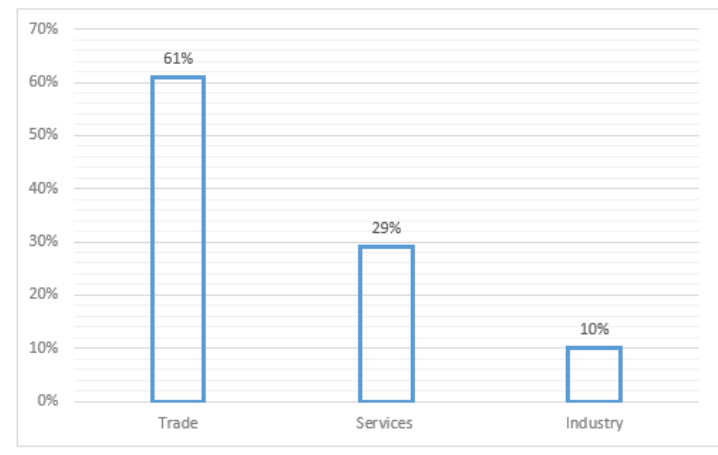

Figure 1. SMEs by sector (ANIF, 2018)

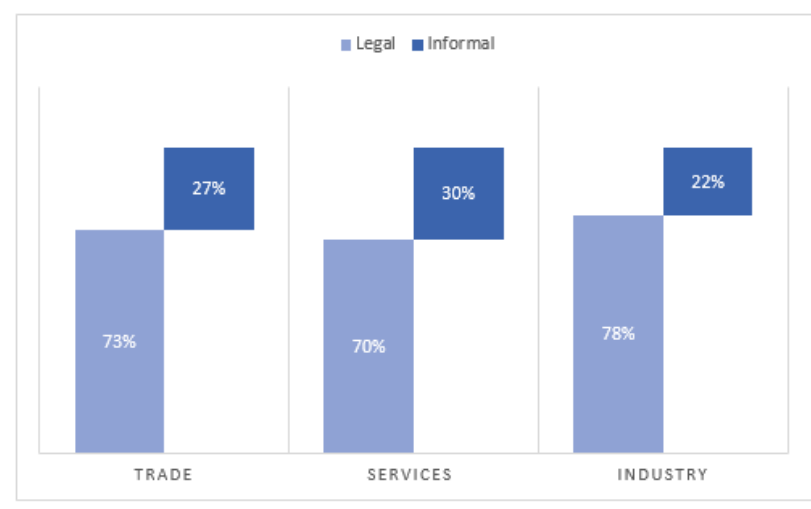

Figure 2. Legalized and informal companies 
According to the figures compiled, $61 \%$ of the companies that participated in the GEM belong to the commercial sector, thus reaffirming that this is the largest share, followed by the services activity and, lastly, the industrial activity. Figure 2 shows the percentage of companies that are currently formally incorporated and those that according to the interview are still in the informal sector.

According to the data, the largest number of formal enterprises is found in industry, followed by the commercial sector and, finally, the service sector. The degree of informality is averaged over the three lines at $26.3 \%$. In exploring the characteristics of the leaders, information was obtained on the age and level of education of the owners, as shown in Table 1.

Table 1. Age of SME owners

\begin{tabular}{|l|c|c|c|c|c|c|}
\hline & \multicolumn{7}{|c|}{ Age } \\
\hline & $\mathbf{1 8 - 2 5}$ & $\mathbf{2 6 - 3 5}$ & $\mathbf{3 6 - 4 5}$ & $\mathbf{4 6 - 5 5}$ & $\mathbf{5 6 - 6 5}$ & $\mathbf{+ 6 5}$ \\
\hline Trade & $11 \%$ & $28 \%$ & $28 \%$ & $20 \%$ & $10 \%$ & $4 \%$ \\
\hline Services & $14 \%$ & $26 \%$ & 265 & $30 \%$ & $10 \%$ & $15 \%$ \\
\hline Industry & $10 \%$ & $22 \%$ & $22 \%$ & $25 \%$ & $11 \%$ & $7 \%$ \\
\hline
\end{tabular}

According to the survey, the age ranges with the highest number of homeowners are between 26 and 55 years of age, respectively, with the lowest participation in the $18-25$ and $65+$ age ranges, as reported. Table 2 shows the educational levels of entrepreneurs.

Table 2. Educational level of entrepreneurs

\begin{tabular}{|l|c|c|c|}
\hline & Secondary school & Technique & Professional \\
\hline Trade & $43 \%$ & $29 \%$ & $13 \%$ \\
\hline Services & $39 \%$ & $29 \%$ & $19 \%$ \\
\hline Industry & $51 \%$ & $22 \%$ & $14 \%$ \\
\hline
\end{tabular}

As can be seen, the predominant educational level is the secondary category, followed by technical or technological training and, ultimately, higher education. In exploring the aspects directly related to the functioning of the SME, the problems related to the improvement plans were addressed, and therefore the problems of financing and continuous improvement are mentioned in Figure 3.

As for the request for resources for the financing of activities, it does not exceed 15\% in both scenarios (legal and informal). With reference to the improvement plans, it was found that they are not being carried out in most SMEs, as projected with the following results in the two scenarios shown in Figure 4.

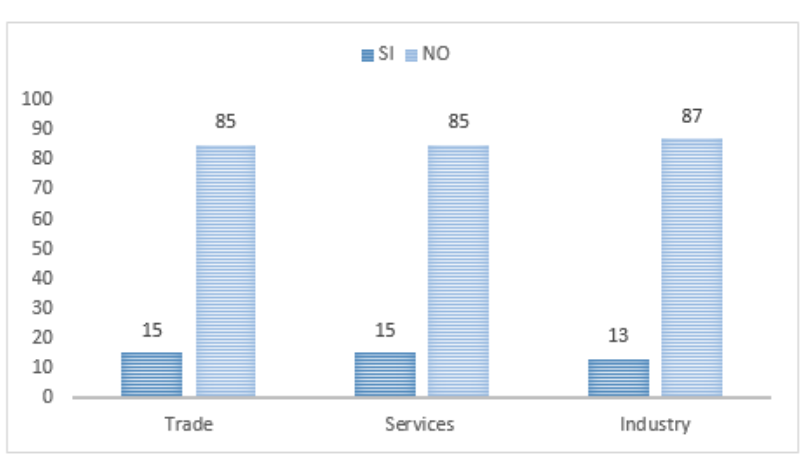

Figure 3. Bank loan application.

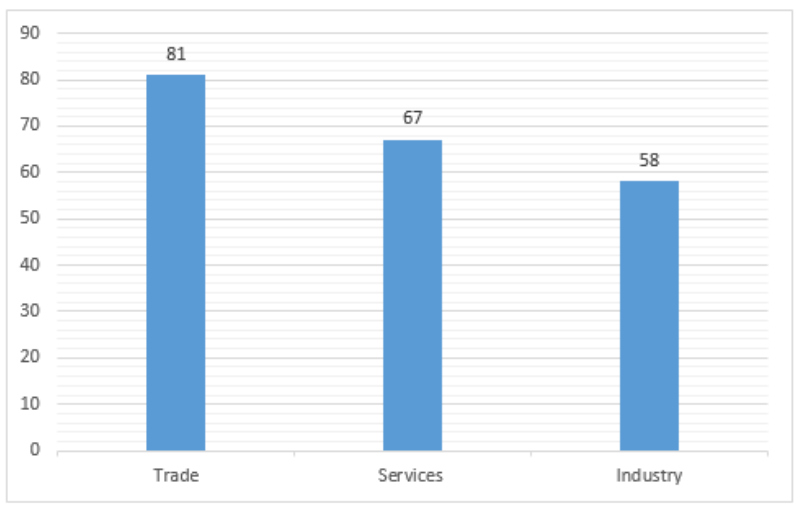

Figure 4. I do not carry out improvement plans in SMEs.

\section{Conclusion}

SMEs continue to be the country's main driving force, especially in terms of job creation. Nevertheless, the characteristics of the Colombian businessperson continue to have characteristics that demand attention, since among the most important aspects we can highlight the low levels of professional training and the refusal to incorporate improvement plans in business.

SMEs continue to be the country's main driving force, especially in terms of job creation. Nevertheless, the characteristics of the Colombian businessperson continue to have characteristics that demand attention, since among the most important aspects we can highlight the low levels of professional training and the refusal to incorporate improvement plans in business. When reflecting on the data cited in this document, it is important to note that in the three sectors with the highest participation of SMEs, the age range is between 26 and 55 years old. Authors such as Wagner have addressed these types of phenomena and Robert, who has stated that as technology and innovation advance, entrepreneurs will start early. 
It is also worth noting that the vast majority of entrepreneurs have only completed secondary education, this reality invites analysis in this regard, since it is estimated that as long as the entrepreneur is trained, his business could have a better chance of survival, lack of tools and academic resources in the field of business, could lead to a risky scenario where resources and strategies could suffer major obstacles, as they have stated in various research related to SMEs globally. On the other hand, when analyzing the issue of financing and improvement plans, there is a certain amount of resistance on the part of employers, since, despite the fact that the vast majority of them are already legalized, they are not turning to financial institutions to resolve possible needs in this regard, this may be influencing the acceptance of improvement plans and opens the door to reflection on possible sources of informal financing, which, being more agile in access, may be pushing the entrepreneur away from the channels set up by the government, the banks and business promotion organizations, these types of phenomena are not exclusive to Colombia and in other countries the subject has already been touched upon, with a very similar scenario.

What is set out in this document shows the need to promote training plans for entrepreneurs, not only because they are starting their activity at an ever younger age, but also because, as long as they have theoretical resources, they will be able to make better decisions that will lead them to forge a more sustainable, secure and long-term scenario. This could benefit the generation of more jobs and at the same time encourage more responsible companies where human and other resources are integrated in a competitive manner.

\section{References}

1. Gupta P, Guha S, Krishnaswami S. Firm growth and its determinants. Journal of Innovation and Entrepreneurship. 2013, 15.

2. Cardona D, Montenegro A, Hernández H. Creación de empresa como pilar para el desarrollo social e integral de la región caribe: Apuntes críticos. Saber, ciencia y libertad. 2017, 12 (1), pp. 130-139.
3. Hernández H, Cardona D, Del Rio J. Direccionamiento Estratégico: Proyección de la Innovación Tecnológica y Gestión Administrativa en las Pequeñas Empresas. Iinformación tecnológica. 2017, 28 (5), pp. 15-22.

4. Martín X, Segredo A, Perdomo I. Capital humano, gestión académica y desarrollo organizacional. Educación Médica Superior. 2013, 27 (3), pp. 288-295.

5. Kramar R. Beyond strategic human resource management: is sustainable human resource management the next approach? The International Journal of Human Resource Management. 2014, 25 (8), pp. 1069-1089.

6. Bamberger P, Biron M, Meshoulam I. Human Resource Strategy. Formulation, Implementation, and Impact. New York: Routledge. 2014, pp. 1-320.

7. Loshali S, Krishnan V. Strategic Human Resource Management and Firm Perfomance: Medianting Role of Transformational Leadership. Journal of Strategic Human Resource Management. 2012, pp. 9-19.

8. Oke A, Walumbwa F, Myers A. Innovation Strategy, Human Resource Policy, and Firms' Revenue Growth: The Roles of Environmental Uncertainty and Innovation Performance. Decision Sciences. 2012, pp. 273-302.

9. García L, García J, Rodríguez A. Impacto de la Inversión en Capitual Humano sobre el Valor Empresarial. Academia, Revista Latinoamericana de Administración. 2012, pp. 15-26.

10. Wagner T, Robert A. Compton. Creating innovators: The making of young people who will change the world. Simon and Schuster. 2015, pp. 1-270.

11. Hulsink W, Daan K. The young, the fast and the furious: a study about the triggers and impediments of youth entrepreneurship. International Journal of Entrepreneurship and Innovation Management. 2014, 18 (2-3), pp. 182-209.

12. Rahman M. Problems and prospects of electronic banking in Bangladesh: A case study on Dutch-Bangla Bank Limited. American Journal of Operations Management and Information Systems. 2017, 2 (1), pp. 42-53.

13. Pitre-Redondo R, Cardona-Arbeláez D, HernándezPalma H. Proyección del emprendimiento indígena como mecanismo de competitividad en el postconflicto colombiano. Revista de Investigación, Desarrollo e Innovación. 2017, pp. 231-240. 